J. Clin. Chem. Clin. Biochem.

Vol. 21, 1983, pp. 765-773

\title{
Foetal and Maternal Magnesium Metabolism: Effect of Magnesium Deficiency and Isoproterenol
}

\author{
By J. Vormann, R. Förster and T. Günther \\ Institut für Molekularbiologie und Biochemie der Freien Universität Berlin
}

(Received May 4/August 17, 1983)

Dedicated to Professor Dr. Dr. Ernst Schütte on the occasion of his 75 th birthday

Summary: Pregnant rats were fed diets with an $\mathrm{Mg}^{2+}$ content of $40,12,6$ and $3 \mathrm{mmol} / \mathrm{kg}$ from day $10-19$ of pregnancy. There was a linear correlation of non-protein bound $\mathrm{Mg}^{2+}$ between foetal and maternal serum, between amniotic fluid and maternal serum, and between foetal serum and amniotic fluid, the ratios being 2.7, 2.0 and 1.3 respectively, indicating active transport of $\mathrm{Mg}^{2+}$ up to a constant concentration gradient by the placenta. In hearts, increases of $\mathrm{Na}^{+}$and $\mathrm{Ca}^{2+}$, and decreases of $\mathrm{Mg}^{2+}$ and $\mathrm{K}^{+}$were observed only in the group receiving the lowest $\mathrm{Mg}^{2+}$ supply.

After i.v. injection of $\mathrm{MgCl}_{2}$ to pregnant rats, $\mathrm{Mg}^{2+}$ was slowly transported from maternal to foetal serum and more slowly into the amniotic fluid.

The effect of isoproterenol on cardiac electrolyte content in pregnant rats was less than in non-pregnant rats, and the effect of isoproterenol in foetal rats was smaller than in maternal rats. These results are explained by inactivation of isoproterenol in the placenta, by the small diaplacental transport of isoproterenol and by a smaller isoproterenol-stimulation of foetal cardiac adenylate cyclase.

Foetaler und maternaler Magnesium-Stoffwechsel: Beeinflussung durch Magnesium-Mangel und durch Isoproterenol

Zusammenfassung: Schwangere Rạtten wurden vom Tag 10 bis 19 der Schwangerschaft mit einer Diät gefüttert, die 40,12,6 und $3 \mathrm{mmol} / \mathrm{kg} \mathrm{Mg}^{2+}$ enthielt. Es ergab sich für das nicht an Protein gebundene $\mathrm{Mg}^{2+}$ eine lineare Korrelation zwișchen foetalem und mütterlichem Serum, zwischen Amnionflüssigkeit und mütterlichem Serum sowie zwischen foetalem Serum und Amnionflüssigkeit. Das Verhältnis der $\mathrm{Mg}^{2+}$ Konzentrationen betrug für die einzelnen Korrelationen 2,7; 2,0 und 1,3. Daraus ergibt sich, daß $\mathrm{Mg}^{2+}$ bis zu einem konstanten Konzenträtionsgradientẹn angereichert wird.

Nur in der Gruppe mit der geringsten $\mathrm{Mg}^{2+}=\mathrm{Zufuhr}$ waren im Herzen der $\mathrm{Na}^{+}$- und $\mathrm{Ca}^{2+}$-Gehalt erhöht und der $\mathrm{Mg}^{2+}$ - und $\mathrm{K}^{+}$-Gehalt erniedrigt.

Nach intravenöser Injektion von $\mathrm{MgCl}_{2}$ wurde $\mathrm{Mg}^{2+}$ nur sehr langsam vom mütterlichen zum foetalen Serum und noch langsamer in die Amnionflüssigkeit transportiert.

Die Wirkung von Isoproterenol auf den Elektrolytgehalt des Herzens war bei schwangeren Ratten wesentlich geringer als bei nicht schwangeren. Bei den Foeten wirkte Isoproterenol noch schwächer als bei den Müttern. Dieses Ergebnis läßt sich mit einer Inaktivierung des Isoproterenols in der Placenta, mit der geringen Placentapassage von Katecholaminen und mit der geringeren Stimulierbarkeit der foetalen Adenylatcyclase durch Isoproterenol erklären. 


\section{Introduction}

In early stages of foetal development in rats $(1,2)$ and chicken (3), the $\mathrm{Mg}^{2+}$ concentration is higher in foetal than in maternal serum and decreases with time. Shortly before birth, the serum $\mathrm{Mg}^{2+}$ concentration is still higher in foetal than in maternal rat serum $(1,2,4)$. During foetal development, the protein concentration in foetal serum increases. However, shortly before birth the protein concentration is still lower in foetal than in maternal rat serum $(1,2)$. Depending on the protein concentration, approximately one third of $\mathrm{Mg}^{2+}$ in serum is bound to protein particularly to albumin (5). Thus, the ratio of non-protein bound $\mathrm{Mg}^{2+}$ in foetal to that in maternal serum is still higher than the ratio of total serum $\mathrm{Mg}^{2+}$. Obviously, the placenta is able to enrich $\mathrm{Mg}^{2+}$ at its foetal site.

When the maternal $\mathrm{Mg}^{2+}$ supply is insufficient, the maternal serum $\mathrm{Mg}^{2+}$ concentration decreases. Below a threshold of, $0.6 \mathrm{mmol} / 1$ (6), foetal retardation and resorption $(6,7,8)$, foetal anaemia (8), malformation $(7,8)$ and a higher mortality of the newborns (7) have been observed, corresponding to the degree of $\mathrm{Mg}$ deficiency. A mild $\mathrm{Mg}$ deficiency in combination with foetal hypotrophy has also been found in some pregnant women particularly during the second half of pregnancy (9). We therefore produced varying degrees of $\mathrm{Mg}$ deficiency in pregnant rats from day 10 to 19 and studied the $\mathrm{Mg}^{2+}$ concentration in serum and amniotic fluid, and the electrolyte contents of hearts and livers from the foetal and maternal rats.

A knowledge of the electrolyte metabolism of foetal hearts in $\mathrm{Mg}$ deficiency is especially interesting because it permits an assessment of the risk of foetal heart damage during tocolysis with $\beta$-agonists; $\beta$-agonists induce a reduction of $\mathrm{Mg}^{2+}$ and an increase in $\mathrm{Ca}^{2+}$ and $\mathrm{Na}^{+}$content in the myocardium followed by necroses of heart muscle cells $(10,11)$. These harmful $\beta$-adrenergic effects can be prevented by a previous $\mathrm{Mg}^{2+}$ supplementation $(10,11)$. On the other hand, the effects of $\mathrm{Mg}$ deficiency and isoproterenol on cardiac electrolytes have been shown to be additive (12). Therefore, we also compared the effect of isoproterenol on the eletrolyte contents of foetal and maternal hearts.

\section{Materials and Methods}

Female Wistar rats weighing $200 \mathrm{~g}$ were maintained under a 12 hour light-dark cycle and at a temperature of about $20^{\circ} \mathrm{C}$. Virgin females were mated from 8-10 a.m. and impregnated females were identified by the presence of copulatory plugs. This day was designated as day 0 of gestation. Up to day 10 , the rats were fed with Altromin ( $\mathrm{Mg}$ content: $80 \mathrm{mmol} / \mathrm{kg}$ ) and tap water ad libitum.

\section{Experimental design}

\section{Experiment}

From day 10-19 of pregnancy, the rats were fed with a synthetic Mg deficient diet (Ssniff, Soest, FRG); its composition has already been described (13). This diet $\left(\mathrm{Ca}^{2+}\right.$ contênt: $\left.250 \mathrm{mmol} / \mathrm{kg}\right)$ was supplemented with $\mathrm{MgCl}_{2}$ to a final $\mathrm{Mg}^{2+}$ content of $40 \mathrm{mmol} / \mathrm{kg}$, $12 \mathrm{mmol} / \mathrm{kg}, 6 \mathrm{mmol} / \mathrm{kg}$, and $3 \mathrm{mmol} / \mathrm{kg}$ (no' supplementation). The rats in each group (number as indicated in tab. 1) were fed with this diet and distilled water ad libitum.

On day 19 , under nembutal anesthesia ( $50 \mathrm{mg} / \mathrm{kg}$ s. c.), amniotic fluid was sampled. Blood was taken from the foetal hearts by means of capillaries and from the mother. The capillaries were closed at one end and centrifuged for $5 \mathrm{~min}$ at $1300 \mathrm{~g}$. Hearts and livers were removed, cleaned in cold sucrose $(100 \mathrm{~g} / 1)$, frozen in liquid nitrogen and freeze-dried. Foetal livers and maternal tissues were pulverized. Foetal serum samples from the same mothers were pooled for determination of $\mathrm{Mg}^{2+}, \mathrm{Ca}^{2+}$ and protein.

\section{Experiment}

On day 19 , under nembutal anesthesia, the arteria and vena rệnalis were ligated in those pregnant rats fed a diet containing 40 $\mathrm{mmol} / \mathrm{kg} \mathrm{Mg}^{2+}$ or $6 \mathrm{mmol} / \mathrm{kg} \mathrm{Mg}^{2+}$ from day $10-19$. Thereafter, the rats were intravenously injected with $0.5 \mathrm{ml} 150 \mathrm{mmol} /$ $\mathrm{MgCl}_{2}$. At various times up to $200 \mathrm{~min}$ p.i. maternal and foetal blood and amniotic fluid were taken.

\section{Experiment}

Normally fed pregnant rats on day 20 of pregnancy were subcüu= taneously injected with $3 \mathrm{mg} / \mathrm{kg}$ isoproterenol. At 2,4 and $6 \mathrm{~h}$ p.i., under nembutal anesthesia, blood, amniotic fluid, livers and hearts were taken from the maternal and foetal rats and treated as described above.

\section{Experiment}

Normally fed male Wistar rats weighing $250 \mathrm{~g}$ were s. c. injected 4 times every other day with $3 \mathrm{mg}$ oestradiol, $3 \mathrm{mg}$ progesterone and with both in combination. After seven days they were injected with $3 \mathrm{mg} / \mathrm{kg}$ isoproterenol. Six hours after injection of isoproterenol the rats were killed.

\section{Analytical procedures}

Protein contents were 'measured in $10 \mu \mathrm{l}$ of foetal and $5 \mu \mathrm{l}$ of maternal serum or $10 \mu \mathrm{l}$ amniotic fluid according to Lowry et al. (14). For the determination of $\mathrm{Mg}^{2+}$ and $\mathrm{Ca}^{2+}, 100 \mu \mathrm{l}$ and $50 \mu \mathrm{l}$ respectively of amniotic fluid or serum were diluted with $1.8 \mathrm{ml}$ trichloroacetic acid $(50 \mathrm{~g} / \mathrm{l})$ containing $1 \mathrm{~g} / 1 \mathrm{La}^{3+}$ and measured in an atomic absorption spectrophotometer (Perkin-Elmer, model 300). Phosphate was determined according to Fiske \& Subbarow (15). Concentrations of non-protein bound $\mathrm{Mg}^{2+}$ and $\mathrm{Ca}^{2+}$ in serum were calculated according to $1 . c .(16,17)$.

For the determination of tissue electrolytes, 3-4 freeze-dried foetal hearts and $20 \mathrm{mg}$ of the other freeze-dried tissues were ashed overnight in a Low Temperature Asher ( $\mathrm{Fa}$. Tracerlab). The ashes were dissolved in $3 \mathrm{ml} 0.1 \mathrm{~mol} / \mathrm{h} \mathrm{HCl}$. For the determination of $\mathrm{Ca}^{2+}, 100 \mu \mathrm{l}$ were diluted with $200 \mu \mathrm{l}$ Millipore water. $20 \mu \mathrm{l}$ in quadruplicates were injected into a graphite furnace and measured according to the Perkin Elmer manual.

For the determination of $\mathrm{Mg}^{2+}, 1 \mathrm{ml}$ was diluted with $2 \mathrm{ml} 1 \mathrm{~g} / \mathrm{l}$ $\mathrm{La}^{3+}$ in $0.1 \mathrm{~mol} / 1 \mathrm{HCl}$ and measured by flame atomic absorption. spectrophotometry. For the determination of $\mathrm{Na}^{+}$and $\mathrm{K}^{+}, 0.5 \mathrm{ml}$ were diluted with $0.5 \mathrm{ml} 30 \mathrm{mmol} / \mathrm{LiCl}$ and measured in a flame photometer (Beckman). All solutions were made with Millipore water.
: 


\section{Statistical treatment}

Determinations in serum and amniotic fluid were done in duplicate. For the analysis of foetal hearts 3-4 hearts were pooled. Other tissue analyses were done with $20 \mathrm{mg}$ aliquots in triplicate.

All values are expressed as means \pm SEM. Tests of significance were made using Student's t-test for unpaired data.

\section{Results}

Serum

When pregnant rats were fed a diet with reduced $\mathrm{Mg}^{2+}$ content, the $\mathrm{Mg}^{2+}$ concentration in maternal and foetal serum was lowered. However, the $\mathrm{Mg}^{2+}$ concentration in foetal serum is always higher than in maternal serum (tab. 1). Under the same experimental conditions, the protein content of maternal and foetal serum remained nearly constant and was always higher in the maternal serum (tab. 1). Calculation of the concentration of non-protein bound $\mathrm{Mg}^{2+}$ for individual maternal and foetal serum, assuming the $\mathrm{pH}$ and albumin-globulin ratio to be the same, showed a linear correlation (fig. 1); the concentration of non-protein bound $\mathrm{Mg}^{2+}$ in fetal serum was 2.7 times higher than in maternal serum over a wide range of $\mathrm{Mg}^{2+}$ concentrations. The $\mathrm{Ca}^{2+}$ concentration in serum was not affected by $\mathrm{Mg}$ deficiency. The concentration of non-protein bound $\mathrm{Ca}^{2+}$ was somewhat higher in foetal than in maternal serum. The difference was not significant (tab. 1).

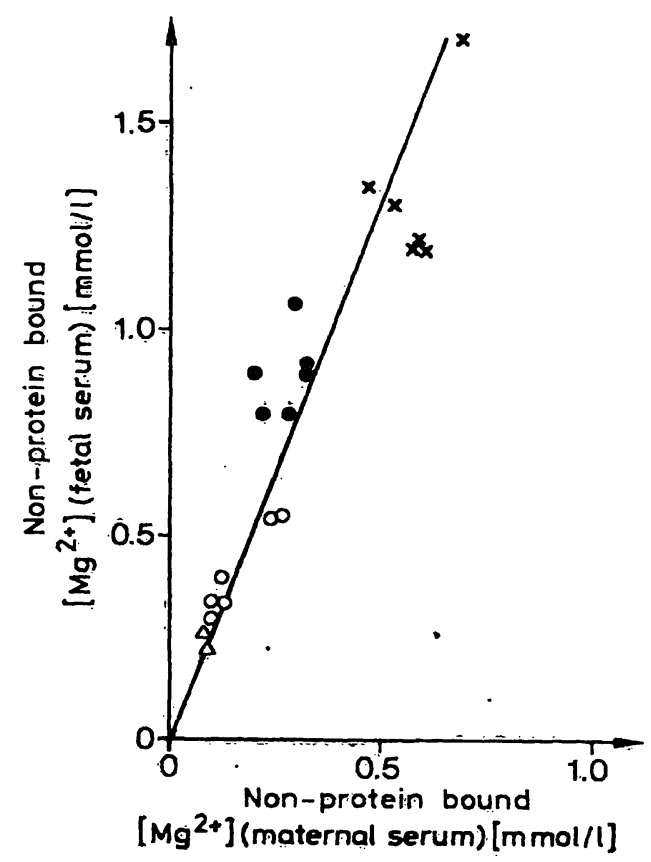

Fig. 1. Correlation of non-protein bound $\mathrm{Mg}^{2+}$ in foetal and maternal serum.

Pregnant rats fed a diet with $40 \mathrm{mmol} / \mathrm{kg} \mathrm{Mg}^{2+}(x), 12$ $\mathrm{mmol} / \mathrm{kg} \mathrm{Mg}^{2+}(0), 6 \mathrm{mmol} / \mathrm{kg} \mathrm{Mg}^{2+}(0)$, and $3 \mathrm{mmol} / \mathrm{kg}$ $\mathrm{Mg}^{2+}(\Delta)$ from day 10 to 19 of pregnancy.

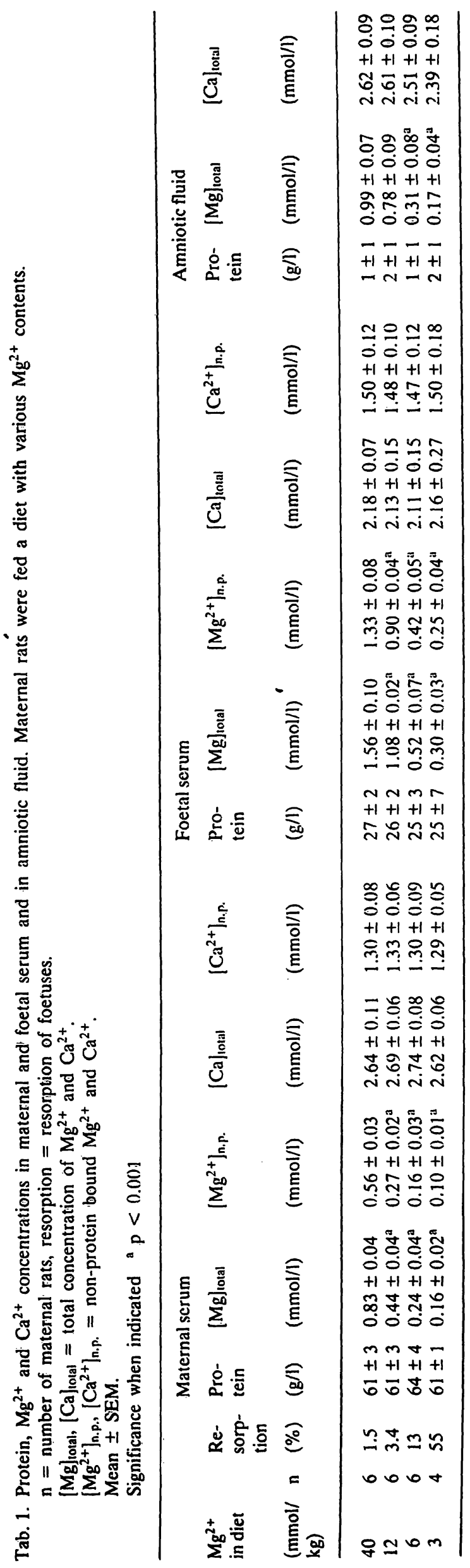


However, other $\mathrm{Ca}^{2+}$ binding substances e.g. phosphate must be considered. In normal foetal and maternal serum we found a phosphate concentration of $4.9 \pm 0.4$ and $2.4 \pm 0.1 \mathrm{mmol} / \mathrm{/}$ respectively. Other authors also found a higher phosphate concentration in foetal serum (2). $\mathrm{Mg}$ deficiency had no effect on the phosphate concentration in serum.

Using the $\mathrm{Mg}^{2+}$-phosphate binding constant of 33 $1 / \mathrm{mol}(18)$, it can be calculated that in maternal rat serum maximally $8 \%$ and in foetal serum maximally $16 \%$ of non-protein bound $\mathrm{Mg}^{2+}$ are bound to phosphate. When binding of $\mathrm{Ca}^{2+}$ to phosphate is taken into account, the effect of phosphate on $\mathrm{Mg}^{2+}$ binding is somewhat lower. Taking this binding into account, the foetal-maternal $\mathrm{Mg}^{2+}$ gradient, which amounts to 2.7 for non-protein bound $\mathrm{Mg}^{2+}$, would be maximally reduced to 2.5 for free $\mathrm{Mg}^{2+}$. Therefore, one can conclude that in the placenta there is a specific $\mathrm{Mg}^{2+}$ transport system, $\mathrm{Ca}^{2+}$ being unaffected.

To test the $\mathrm{Mg}^{2+}$ transporting capacity of the placenta, the maternal serum $\mathrm{Mg}^{2+}$ concentration was elevated by i.v. injection of $\mathrm{MgCl}_{2}$. Thirty minutes after injection of $0.5 \mathrm{ml} 0.15 \mathrm{~mol} / 1 \mathrm{MgCl}_{2}$, the total $\mathrm{Mg}^{2+}$ in maternal serum of normally fed rats was increased to $4.3 \pm 0.2 \mathrm{mmol} / \mathrm{l}$, and thereafter decreased continuously; after $200 \mathrm{~min}$, the maternal serum $\mathrm{Mg}^{2+}$ concentration was $2.3 \pm 0.2 \mathrm{mmol} / \mathrm{l}$. The simultaneously measured foetal serum $\mathrm{Mg}^{2+}$ concentration increased only slowly. During the experimental period up to 200 min no steady state was reached. When the non-protein bound $\mathrm{Mg}^{2+}$ concentration was calculated and plotted (fig. 2) it was apparent that the foetalmaternal $\mathrm{Mg}^{2+}$ concentration gradient was different from that under physiological conditions. After injection of $\mathrm{MgCl}_{2}$, the free $\mathrm{Mg}^{2+}$ concentration is higher in maternal than in foetal serum. Therefore, under these experimental conditions, net placental $\mathrm{Mg}^{2+}$ transport occurred along the concentration gradient and was low. When the same experiment was done with $\mathrm{Mg}$-deficient rats the same result was obtained although at a lower $\mathrm{Mg}^{2+}$ concentration. In both experiments, the increase of foetal serum $\mathrm{Mg}^{2+}$ amounted to $0.08 \mathrm{mmol} / \mathrm{l} \times$ hour.

In lymphoma cells (19) $\mathrm{Mg}^{2+}$ transport can be inhibited by isoproterenol. Therefore, foetal-maternal $\mathrm{Mg}^{2+}$ distribution was measured 2, 4 and 6 hours after injection of $3 \mathrm{mg} / \mathrm{kg}$ isoproterenol to pregnant rats. As can be seen from table 2, the foetal $\mathrm{Mg}^{2+}$ serum concentration was reduced, particularly $2 \mathrm{~h}$ after injection, and increased again later. Maternal serum $\mathrm{Mg}^{2+}$ behaved inversely to foetal serum $\mathrm{Mg}^{2+}$. Maternal serum $\mathrm{Mg}^{2+}$ was elevated by isoproterenol, due to $\mathrm{Mg}^{2+}$ release from the maternal heart, and

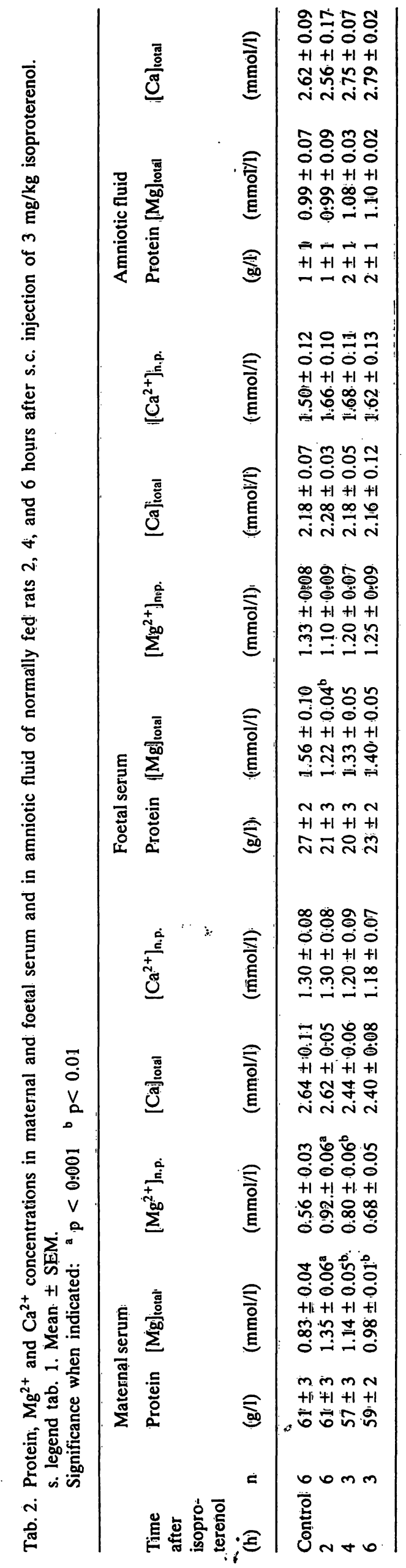


probably by foetal $\mathrm{Mg}^{2+}$ diffusing from foetal serum to maternal serum along the concentration gradient. The latter conclusion is supported by the fact that isoproterenol reduced foetal serum $\mathrm{Mg}^{2+}$ but did not change the foetal cellular $\mathrm{Mg}^{2+}$ content (s. below, tab. 4). $\mathrm{Ca}^{2+}$ and protein concentrations in maternal and foetal serum were not affected by isoproterenol.

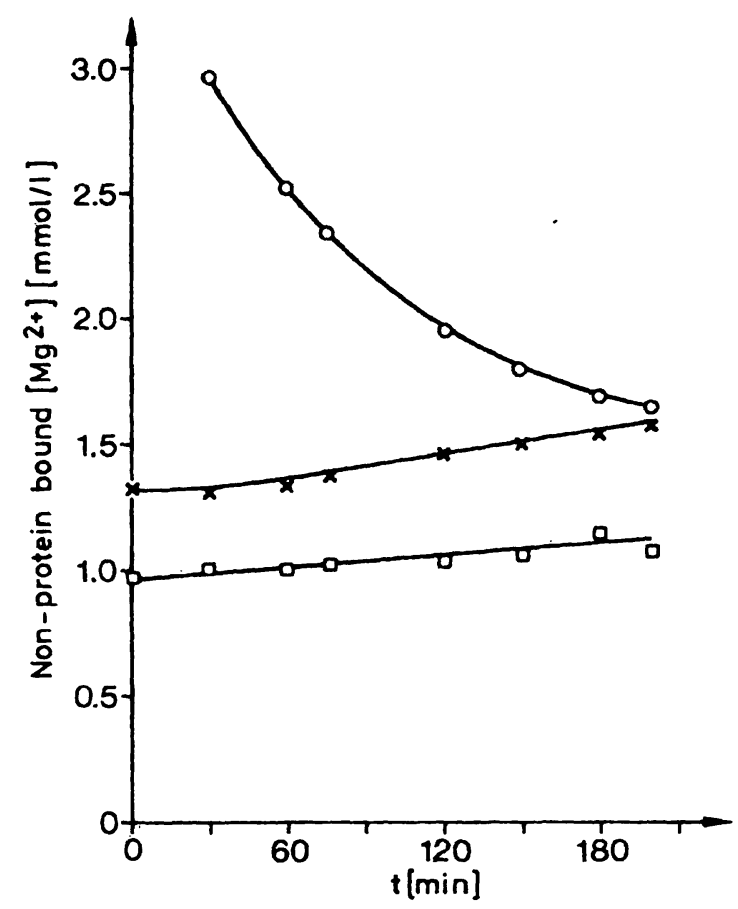

Fig. 2. Non-protein bound $\mathrm{Mg}^{2+}$ in maternal $(0)$ and foetal $(x)$ serum and in amniotic fluid $(\square)$ at different times after intravenous injection of $0.5 \mathrm{ml} 0.15 \mathrm{mmol} / \mathrm{MgCl}$ to pregnant rats after ligation of renal veins and arteries.

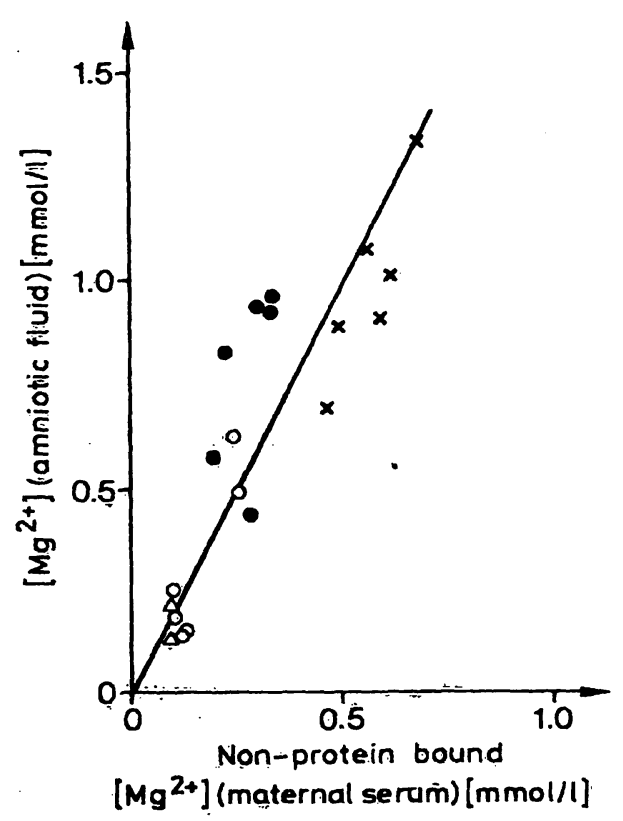

Fig. 3. Correlation of non-protein bound $\mathrm{Mg}^{2+}$ in amniotic fluid and maternal serum. Symbols as in fig. 1.

\section{Amniotic fluid (tab. 1, 2)}

Since the protein and phosphate contents in amniotic fluid are very low $\left(\left[\mathrm{P}_{\mathrm{i}}\right]=0.9 \pm 0.1 \mathrm{mmol} / \mathrm{l}\right)$, total $\mathrm{Mg}^{2+}$ and total $\mathrm{Ca}^{2+}$ concentrations are only somewhat higher than the concentration of free $\mathrm{Mg}^{2+}$ and free $\mathrm{Ca}^{2+}$. When the $\mathrm{Mg}^{2+}$ content in the diet was reduced, the total $\mathrm{Mg}^{2+}$ concentration in the amniotic fluid was also reduced. As in the case of foetal serum, the $\mathrm{Mg}^{2+}$ concentration in the amniotic fluid also exhibited a linear correlation when the $\mathrm{Mg}^{2+}$ concentration in amniotic fluid was plotted versus non-protein bound $\mathrm{Mg}^{2+}$ in maternal serum, the $\mathrm{Mg}^{2+}$ concentration in amniotic fluid being always twice that of non-protein bound $\mathrm{Mg}^{2+}$ in maternal serum (fig. 3). As the phosphate concentration in amniotic fluid is lower than in maternal serum, the effect of phosphate on $\mathrm{Mg}^{2+}$ binding can be neglected. When the $\mathrm{Mg}^{2+}$ concentration in amniotic fluid was correlated with the concentration of non-protein bound $\mathrm{Mg}^{2+}$ in foetal serum, a linear correlation was again obtained; the concentration of non-protein bound $\mathrm{Mg}^{2+}$ in foetal serum is about $30 \%$ higher than total $\mathrm{Mg}^{2+}$ in amniotic fluid (fig. 4).

The linear relationships indicate that there is a steady state of $\mathrm{Mg}^{2+}$ distribution between these fluids in the $\mathrm{Mg}$ deficiency experiment. After injection of $\mathrm{MgCl}_{2}$, $\mathrm{Mg}^{2+}$ uptake into the amniotic fluid was still slower than $\mathrm{Mg}^{2+}$ uptake into foetal serum (fig. 2). In normal and $\mathrm{Mg}$ deficient rats the increase of $\mathrm{Mg}$ in the amniotic fluid amounted to $0.03 \mathrm{mmol} / \mathrm{l} \times \mathrm{h}$. After injection of $3 \mathrm{mg} / \mathrm{kg}$ isoproterenol, the $\mathrm{Mg}^{2+}$ concen-

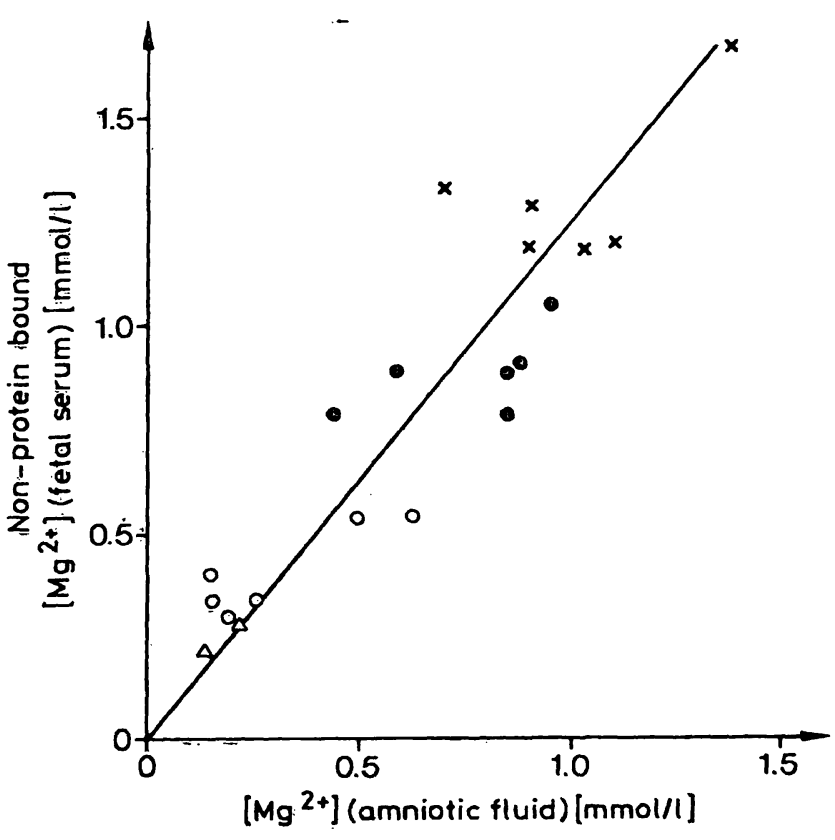

Fig. 4. Correlation of non-protein bound $\mathrm{Mg}^{2+}$ in foetal serum and amniotic fluid. Symbols as in fig. 1. 
tration in amniotic fluid was not significantly changed. The $\mathrm{Mg}^{2+}$ concentration gradient between foetal serum and amniotic fluid was reduced from 1.35 to 1.1 (from tab. 1), due to the decrease of $\mathrm{Mg}^{2+}$ in foetal serum.

Interestingly, because of the low protein and phosphate content, the non-protein bound $\mathrm{Ca}^{2+}$ concentration in the amniotic fluid is higher than in foetal and maternal serum. As yet, we have no explanation for this observation. In $\mathrm{Mg}$ deficiency and after injection of $\mathrm{MgCl}_{2}$ or isoproterenol, the $\mathrm{Ca}^{2+}$ concentration in the amniotic fluid was not changed.

\section{Tissue electrolyte contents (tab. 3,4 )}

On a dry weight basis, the electrolyte contents are higher in foetal than maternal tissues with the exception of $\mathrm{Ca}^{2+}$ in foetal liver.

As $\mathrm{Mg}^{2+}$ and $\mathrm{K}^{+}$have a predominantly intracellular location, foetal liver and myocardial cells have a higher content of $\mathrm{Mg}^{2+}$ and a higher intracellular $\mathrm{K}^{+}$ concentration. In earlier experiments with foetal rat liver (1) we showed that although there was a higher total $\mathrm{Mg}^{2+}$ content, the concentration of free $\mathrm{Mg}^{2+}$ was not enhanced in foetal liver, indicating a higher amount of bound $\mathrm{Mg}^{2+}$. This effect can be explained by the greater number of ribosomes in foetal than in maternal tissues and by the $\mathrm{Mg}^{2+}$ binding properties of these organelles.
The higher content of the preponderantly extracellularly localized $\mathrm{Na}^{+}$may be due to the higher extracellular fluid volume in foetal tissues. After feeding the diets with low $\mathrm{Mg}^{2+}$ contents, $\mathrm{Na}^{+}$and $\mathrm{Ca}^{2+}$ contents in maternal foetal heart were elevated, and $\mathrm{K}^{+}$ and $\mathrm{Mg}^{2+}$ contents were reduced. The effect was only significantly expressed in the group fed with 3 $\mathrm{mmol} / \mathrm{kg} \mathrm{Mg}^{2+}$. In liver the effect of $\mathrm{Mg}$ deficiency is smaller than in heart (20). Thus, no effect was observed in maternal liver, owing to the short experimental period, whereas foetal livers showed similar (but non-significant) changes to those observed in the heart (tab. 3).

In foetal tissues the $\mathrm{Mg}$ deficiency-induced alterations in electrolyte content were more pronounced than in maternal tissues. This can be explained by the higher growth rate of foetal tissues, because the $\mathrm{Mg}$ deficiency-induced alterations in electrolyte content depend on growth rate (20).

After injection of $3 \mathrm{mg} / \mathrm{kg}$ isoproterenol $\mathrm{Na}^{+}$and $\mathrm{Ca}^{2+}$ contents in the maternal hearts were increased, whereas the $\mathrm{Mg}^{2+}$ content was decreased 2 hours p.i. and was normalized thereafter. The $\mathrm{K}^{+}$content was not significantly changed. Thus the alterations are qualitatively similar to the alterations of electrolyte content, as found in experiments with male rats (12). However, the effects of $3 \mathrm{mg} / \mathrm{kg}$ isoprotèrènol in pregnant rats were much smaller than those observed for the same dose in male rats. In the foetal hearts the effect of isoproterenol was even smaller than in maternal hearts (tab: 4).

Tab. 3. Electrolyte content in maternal and foetal heart and liver after feeding a diet of different $\mathbf{M g}^{2+}$ content from day 10 to 19 of pregnancy. Mean $\pm S E M, n=$ number of pregnant rats. Significance ${ }^{\mathrm{a}} \mathrm{p}<0.001^{\mathrm{b}} \mathrm{p}<0.01^{\mathrm{c}} \mathrm{p}<0.05$

\begin{tabular}{|c|c|c|c|c|c|c|c|}
\hline $\begin{array}{l}\mathrm{Mg}^{2+} \\
\text { in diet } \mathrm{n} \\
(\mathrm{mmol} / \\
\mathrm{kg})\end{array}$ & $\begin{array}{l}\mathrm{Mg}^{2+} \\
\text { (mmol/kg dry weight) }\end{array}$ & $\mathrm{Na}^{+}$ & $\mathrm{K}^{+}$ & $\begin{array}{l}\mathrm{Mg}^{2+} \\
(\mathrm{mmol}\end{array}$ & $\begin{array}{l}\mathrm{Ca}^{2+} \\
\text { veight) }\end{array}$ & $\mathrm{Na}^{+}$ & $\mathrm{K}^{+}$ \\
\hline
\end{tabular}

\begin{tabular}{|c|c|c|c|c|c|c|c|c|c|}
\hline \multirow{3}{*}{$\begin{array}{l}40 \\
12\end{array}$} & \multirow[b]{2}{*}{6} & \multicolumn{4}{|c|}{ Maternal heart } & \multicolumn{4}{|c|}{ Foetal heart } \\
\hline & & $38.0 \pm 0.3$ & $2.6 \pm 0.1$ & $142 \pm 4$ & $347 \pm 8$ & $41.9 \pm 0.6$ & $4.6 \pm 0.3$ & $218 \pm 10$ & $468 \pm 8$ \\
\hline & 6 & $38.0 \pm 1.1$ & $2.9 \pm 0.1$ & $141 \pm 5$ & $328 \pm 9$ & $42.2 \pm 0.7$ & $4.6 \pm 0.4$ & $215 \pm 8$ & $459 \pm 6$ \\
\hline 6 & 6 & $37.6 \pm 0.9$ & $2.9 \pm 0.1$ & $137 \pm 4$ & $327 \pm 5$ & $40.1 \pm 0.9$ & $5.0 \pm 0.3$ & $244 \pm 9$ & $455 \pm 8$ \\
\hline 3 & 4 & $34.1 \pm 1.0^{\mathrm{b}}$ & $3.2 \pm 0.9$ & $155 \pm 3^{c}$ & $296 \pm 4^{a}$ & $36.8 \pm 1.2^{c}$ & $6.5 \pm 0.9$ & $249 \pm 8^{c}$ & $.382 \pm 34^{c}$ \\
\hline . & & \multicolumn{4}{|c|}{ Maternal liver } & \multicolumn{2}{|l|}{ Foetal liver } & \multicolumn{2}{|c|}{$\therefore$} \\
\hline 40 & 6 & $31.4 \pm 0.6$ & $3.0 \pm 0.2$ & $69 \pm 3$ & $355 \pm 12$ & $38.2 \pm 1.0$ & $2.4 \pm 0.3$ & $147 \pm 6$ & $451 \pm 20$ \\
\hline 12 & 6 & $31.8 \pm 0.5$ & $3.2 \pm 0.1$ & $68 \pm 1$ & $354 \pm 7$ & $38.7 \pm 0.8$ & $2.6 \pm 0.2$ & $152 \pm 11$ & $472 \pm 24$ \\
\hline 6 & 6 & $31.2 \pm 1.0$ & $3.2 \pm 0.1$ & $71 \pm 3$ & $351 \pm 9$ & $37.7 \pm 1.7$ & $2.4 \pm 0.1$ & $168 \pm 3$ & $465 \pm 25$ \\
\hline 3 & 4 & $31.2 \pm 2.3$ & $3.0 \pm 0.2$ & $75 \pm 6$ & $359 \pm 17$ & $34.1 \pm 1.5$ & $2.6 \pm 0.3$ & $171 \pm 8$ & $431 \pm 25$ \\
\hline
\end{tabular}


Tab. 4. Electrolyte content of maternal and foetal heart 2,4 and 6 hours after s.c. injection of $3 \mathrm{mg} / \mathrm{kg}$ isoproterenol. Mean \pm SEM. $\mathrm{n}=$ number of pregnant rats.

Significance when indicated: $a<0.001{ }^{b} p<0.01{ }^{c} p<0.05$.

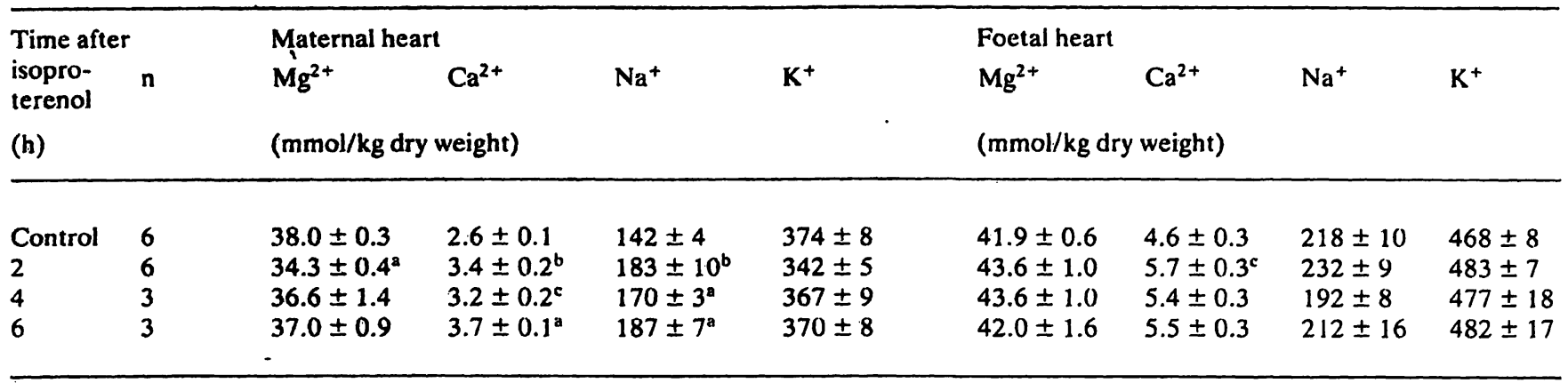

Following the injection of isoproterenol, maternal and foetal livers showed no alteration of electrolyte contents (not shown). This result is in agreement with the finding of others (21), demonstrating that isoproterenol has a rather cardiospecific effect.

The very low effect of isoproterenol in pregnant rats was not caused by the changed hormonal situation in pregnancy. Injection of isoproterenol into non-pregnant female rats, male rats and male rats pretreated with oestradiol, progesterone and oestradiol-progesterone in combination produced the same alterations in cardiac electrolyte content as described for male rats (12), particularly the drastic increase in cardiac $\mathrm{Ca}^{2+}$ content from 2.8 in normal rats to $9 \mathrm{mmol} / \mathrm{kg}$ dry weight.

Therefore, one can conclude, that in pregnant rats the placenta was responsible diminishing the effect of isoproterenol on the maternal myocardial electrolyte content.

\section{Discussion}

Our results indicate that there is an active transport of $\mathrm{Mg}^{2+}$ in the placenta. It seems reasonable to correlate the placental $\mathbf{M g}^{2+}$ transport with the syncytium covering the foetal capillaries. The syncytium contains a brush border like intestinal epithelial cells and may be able to transport $\mathrm{Mg}^{2+}$.

This function may be in analogy to the $\mathrm{Mg}^{2+}$ transport by the epithelial layer of the chorioid plexus, resulting in an increased $\mathrm{Mg}^{2+}$ concentration in the cerebrospinal fluid (22). However, the direction of $\mathrm{Mg}^{2+}$ transport would be opposite in these two epithelial layers.
Placental $\mathrm{Mg}^{2+}$ transport operates with unchanged efficiency during $\mathrm{Mg}$ deficiency, always producing the same $\mathrm{Mg}^{2+}$ concentration gradient over a wide range of free $\mathrm{Mg}^{2+}$ concentrations ( 0.1 to 0.6 $\mathrm{mmol} / \mathrm{l}$ ) in serum. Therefore, maternal serum $\mathrm{Mg}^{2+}$ concentrations can be used as an index of foetal serum $\mathrm{Mg}^{2+}$ concentrations. However, there is disagreement on the concentration range. Dancis et al. (4) found that the $\mathrm{Mg}^{2+}$ concentration gradient broke down in $\mathrm{Mg}$ deficiency. It is possible that the latter result was due to by foetal death.

The capacity of net $\mathrm{Mg}^{2+}$ transport in the placenta is rather limited. After elevation of maternal serum $\mathrm{Mg}^{2+}$ concentration by i.v. $\mathrm{MgCl}_{2}$ injection, foetal $\mathrm{Mg}^{2+}$ concentration increased only slowly. In this experiment the maternal serum $\mathrm{Mg}^{2+}$ concentration, increased by i.v. $\mathrm{MgCl}_{2}$ injection, decreased rapidly. Since renal excretion was eliminated and foetal $\mathrm{Mg}^{2+}$ uptake was rather slow, the injected $\mathrm{Mg}^{2+}$ must have been taken up by maternal tissues, particularly by maternal bone. Bone contains about $50 \%$ of total body $\mathrm{Mg}^{2+}$, and $\mathrm{Mg}^{2+}$ in bone is in equilibrium with extracellular $\mathrm{Mg}^{2+}(5)$. In agreement with this conclusion, injected ${ }^{28} \mathrm{Mg}^{2+}$ was rapidly removed from maternal serum with a similar time course and was rapidly taken up particularly by maternal bone (23) (essentially by isotopic ${ }^{28} \mathrm{Mg}^{2+}-{ }^{24} \mathrm{Mg}^{2+}$-exchange).

In agreement with the slow net placental $\mathrm{Mg}^{2+}$ transport, ${ }^{28} \mathrm{Mg}^{2+}$ transport (exchange) to foetal serum was also limited. Immediately after i.v. injection, ${ }^{28} \mathrm{Mg}^{2+}$ activity in foetal serum reached an almost constant but low level (23). From this result one can conclude that the single ${ }^{28} \mathrm{Mg}^{2+}$ ion is transported rapidly across the placenta. However, the number of transported ${ }^{28} \mathrm{Mg}^{2+}$ ions was rather limited and ${ }^{28} \mathrm{Mg}^{2+}$ that had crossed the placenta was rapidly exchanged with foetal tissue $\mathrm{Mg}^{2+}$. 
To define active placental $\mathrm{Mg}^{2+}$ transport, the electrical potential difference must be considered. The transplacental electrical potential difference amounted to $50 \mathrm{mV}$ in sheep and to $70 \mathrm{mV}$ in goats (foetus negative) (24). However, there was no concentration gradient between foetal and maternal serum for $\mathrm{Na}^{+}$and $\mathrm{K}^{+}(4,24,25)$. There is no explanation for this effect. Considering the transplacental potential difference of $50-70 \mathrm{mV}$ (foetus negative) and the $\mathrm{Mg}^{2+}$ concentration gradient, there should be an active $\mathrm{Mg}^{2+}$ transport from foetal to maternal serum if placental $\mathrm{Mg}^{2+}$ transport depends on the potential difference. However, it is possible that placental $\mathrm{Mg}^{2+}$ transport is independent of membrane potential.

Thus placental $\mathrm{Mg}^{2+}$ transport exhibits similar properties to cellular $\mathrm{Mg}^{2+}$ transport. Intracellular free $\mathrm{Mg}^{2+}$ concentration is also $2-3$ times higher than extracellular free $\mathrm{Mg}^{2+}(20)$ and is probably independent of membrane potential.

$\mathrm{Mg}^{2+}$ transport by lymphoma cells (19) involves the $\beta$-receptor-adenylate cyclase complex. A similar effect may be involved in placental $\mathrm{Mg}^{2+}$ transport. After isoproterenol injection there was a transient decrease in foetal $\mathrm{Mg}^{2+}$ serum concentration.

This may be caused by a net flux of $\mathrm{Mg}^{2+}$ from foetal to maternal serum along the $\mathrm{Mg}^{2+}$ concentration gradient. It is possible that the inhibition of placental $\mathrm{Mg}^{2+}$ transport is caused by isoproterenol-stimulation of adenylate cyclase similar to that in lymphoma cells (19).

\section{References}

1. Günther, T. (1966) Naturwiss. 53, 554.

2. Garel, J. M. \& Barlet, J. P. (1974) J. Endocrinol. 61, 1-13.

3. Taylor, T. G. (1963) Biochem. J. 87, 7 P.

4. Dancis, J., Springer, D. \& Cohlan, S. Q. (1971) Pediatr. Res. $5,131-136$

5. Ebel, H. \& Günther, T. (1980) J. Clin. Chem. Clin. Biochem. $18,257-270$.

6. Günther, T., Ising, H., Mohr-Nawroth, F., Chahoud, I. \& Merker, H. J. (1981) Teratology 24, 225-233.

7. Günther, T., Dorn, F. \& Merker, H. J. (1973) Z. Klin. Chem. Klin. Biochem. 11, 87-92.

8. Hurley, L. S. (1981) Magnesium-Bull. 3 [1a], 202-208.

9. Conradt, A. \& Weidinger, H. (1982) Magnesium-Bull. 4, 103-124.

10. Lehr, D., Chau, R. \& Irene, S. (1975) Recent Advances in Studies on Cardiac Structure and Metabolism 6, 95-109.

11. Fleckenstein, A., Janke, J., Frey, M. \& Hein, B. (1977) Arzneimittelforsch. 27, 382-389.

12. Vormann, J., Günther, T. \& Leder, O. (1981) MagnesiumBull. 3, 130-134.

13. Günther, T., Vormann, J., Merker, H. J., Averdunk, R., Peter, H. W., Wonigeit, K. Magnesium Exp. Clin. Res. (in press).
A striking effect is the drastically reduced action of isoproterenol in pregnant rats and in their foetuses after a single injection, in comparison with normal rats. Since pretreatment with corticoids alters isoproterenol-sensitivity (26) the effect of pretreatment with oestradiol and progesterone was tested. However, pretreatment with these hormones did not alter the isoproterenol response. Therefore, the placenta seems to reduce the isoproterenol action, probably by inactivating isoproterenol. The main biotransformation of isoproterenol is conversion to 3-O-methylisoproterenol by the action of catechol-O-methyltransferase (COMT) (27). As the placenta contains monoamine oxidase (MAO) and catechol-O-methyltransferase (for literature, see l.c. (28)), this reaction can occur. The physiological significance may be the protection of the foetus against harmful effects of catecholamines. This effect is supported by the very low diaplacental passage of catecholamines $(28,29,30)$.

In late pregnancy in the myocardium of foetal rats and rabbits the number and affinity of $\beta$-adrenergic receptors are fully developed $(31,32,33)$. However, maximal stimulation of adenylate cyclase by $\beta$-agonists in foetal hearts is lower than that of adult hearts $(32,34)$. The small isopioterenol response of the foetuses can be explained by the sum of these effects and by the higher foetal serum $\mathrm{Mg}^{2+}$ concentration. If applicable to humans, these results show that the foetus is more protected than its mother during tocolysis with $\beta$-agonists.

14. Lowry, O. H., Rosebrough, N. J., Farr, A. L. \& Randall, R. J. (1951) J. Biol. Chem. 193, 265-275.

15. Fiske, C. H. \& Subbarow, Y. (1925) J. Biol. Chem. 66, 375400 .

16. Willis, M. J. \& Sunderman, F. W. (1952) J. Biol. Chem. 197, 343-345.

17. McLean, F. C. \& Hastings, A. B. (1935) J. Biol. Chem. 108 , 285-322.

18. Trevelyan, W. E., Mann, P. F. E. \& Harrison, J. S. (1952) Arch. Biochem. Biophys. 39, 440-449.

19. Maguire, M. E. \& Erdos, J. J. (1980) J. Biol. Chem. 255, $1030=1035$.

20. Günther, T. (1981) Magnesium-Bull. 3 (1a), 91-101.

21. Abraham, A. S., Bar-On, E. \& Eyylath, U. (1981) Medical Biol. 59, 99-102.

21. Chutkow, J. G. (1971) I. International Symposium on Magnesium Deficit in Human Pathology. Vittel, p. 113-134.

23. Aikawa, J. K. \& Bruns, P: D. (1960) Proc. Soc. Exptl. Biol. Med. 105, 95-98.

24. Mellor, D. J. (1970) J. Physiol. 207, 133-150.

25. Bradbury, M: W. B., Crowder, J., Desai, S., Reynolds, J. M., Reynolds, M. \& Saunders, N. R. (1972) J. Physiol. 227, $591-610$. 
26. Guideri, G., Green, M. \& Lehr, D. (1978) Res. Commun. Chem. Pathol. Pharmacol. 21, 197-212.

27. Rahn, K. H. (1980) in: Handbook of Experimental Pharmacology (Born, G. V. R., Farah, A., Herken, H. \& Welch, A. D. eds.) Vol. 54, Part 2, p. 365-383, Springer Verlag.

28. Saarikoski, S. (1974) Acta Physiol. Scand. Suppl. 421, 1-82.

29. Kramer, I. \& Klingspohr, H. J. (1974) Arzneimittelforsch. 24, 1210-1213.

30. Meißner, J. \& Preil, P. (1974) Arzneimittelforsch. 24, 12131217.
31. Martin, S., Levey, B. A. \& Levey, G. S. (1973) Biochem. Biophys. Res. Commun. 54, 949-954.

32. Schumacher, W. A., Sheppard, J. R. \& Mirkin, B. L. (1979) Fed. Proc. 38, 533.

33. Whitset, J. A. \& Darovec-Beckerman, D. (1981) Pediat. Res. 15, 1363-1369.

34. Schumacher, W. A., Sheppard, J. R. \& Mirkin, B. L. (1982) J. Pharmacol. ExptI. Therap. 233, 587-593.

Professor Dr. T. Günther

Institut für Molekularbiologie und Biochemie

Freie Universität Berlin

Arnimallee 22

D-1000 Berlin 33 
